AperTO - Archivio Istituzionale Open Access dell'Università di Torino

\title{
Fungal bioremediation of emerging micropollutants in municipal wastewaters
}

\section{This is a pre print version of the following article:}

Original Citation:

\section{Availability:}

This version is available http://hdl.handle.net/2318/1573173

since 2016-10-18T14:23:36Z

Publisher:

Diane Purchase

Published version:

DOI:10.1007/978-3-319-42852-9

Terms of use:

Open Access

Anyone can freely access the full text of works made available as "Open Access". Works made available under a Creative Commons license can be used according to the terms and conditions of said license. Use of all other works requires consent of the right holder (author or publisher) if not exempted from copyright protection by the applicable law. 


\section{IIIS AperTO}

UNIVERSITÀ

DEGLI STUDI

DI TORINO

This is the author's final version of the contribution published as:

Spina F., Varese G.C. (2016). Fungal bioremediation of emerging micropollutants in municipal wastewaters. In: Fungal Applications in Sustainable Environmental Biotechnology. Ed. Springer.

The publisher's version is available at:

http://www.springer.com/us/book/9783319428505\#aboutBook

When citing, please refer to the published version.

Link to this full text:

http://hdl.handle.net/2318/1573173 
Fungal bioremediation of emerging micropollutants in municipal wastewaters

Federica Spina and Giovanna Cristina Varese

University of Torino

Department of Life Sciences and System Biology

Mycotheca Universitatis Taurinensis (MUT)

Viale Mattioli 25

10125 - Torino, Italy

federica.spina@unito.it

cristina.varese@unito.it 


\section{Table of contents}

1. Introduction

2. Fungal treatment

3. Enzymatic treatment

3.1 Fungal peroxidases

3.2 Fungal laccases

3.2.1 Laccase mediated system

3.2.2 Effect of reaction conditions on micropollutants degradation

\subsubsection{Laccases stability}

3.2.4 Laccases vs municipal wastewaters

4. Toxicity evaluation

5. Conclusion 


\begin{abstract}
(10-15 line long)
Nowadays, the presence of emerging micropollutants is one of the main issues related to the release into the environment of municipal wastewaters. Considering that wastewater treatment plants are not specifically designed for remove them, fungi and their enzymes are among the most promising solutions to the problem. The current state of research is described in the chapter, highlighting the major achievements obtained so far by researchers for the conversion of emerging micropollutants such as EDCs, PCPs, biological active compounds, etc. Advantages and disadvantages in the use of fungal whole-cell systems or of their enzymes as crude extracts or purified enzymes have been taken into consideration. Some operative (addition of nutrient, $\mathrm{pH}$ control, etc.) and technological solutions (mediator addition, immobilization of the biocatalysts, etc.) able to enhance the effectiveness and the stability of biological treatments are also presented.

Since the removal of pollutants and the abatement of the toxicity are the two main goals of any treatment, water quality assessment requires targeted analysis to investigate the biological effect that samples could have on aquatic organisms and human health by monitoring the ecotoxicity and the estrogenic activity. Even though bioassays are not a routine practice, they have often been used to assess the efficacy of fungal and enzymatic processes.
\end{abstract}

\title{
Key Words (5-10)
}

Emerging micropollutants, EDCs, white rot fungi, laccases, estrogenic activity, ecotoxicity 


\section{Introduction}

Over the last decades, clean and safe waters became a major concern of modern society. International legislations have been developed accordingly, gradually reducing emissions and losses of priority hazardous substances.

Through years, global industrialization and human habits evolved affecting deeply the condition of superficial waters worldwide. A new concept of priority substances has to be drawn, including those compounds that have never considered before; due to improved techniques that lowered levels of detection, many chemicals have been discovered in watercourses. Although no regulatory standard has been set for most of these substances, more and more evidences demonstrated their environmental relevance.

The Environmental Protection Agency (EPA) began to handle with this issue in the early-1990s, introducing the term emerging contaminants. European Commission (EC) followed with few initiatives aimed to monitor aquatic environment and to assess chemicals risk, leading to the Directive 2013/39/EU. European Commission recently required more detailed information on the effects of up to 30,000 chemicals (Sung et al. 2012). A watch list of compounds including estrogens, herbicides, pesticides, anti-inflammatory drugs and sunscreen ingredients was outlined. These chemicals are not necessarily new, being part of the industrial and manufacturing chain but their environmental significance emerged only recently.

Why should emerging contaminants be our concern? Public concern has risen due to the possible interference with the physiological functioning of human and wildlife endocrine systems. A primary issue is represented by Endocrine Disrupting Chemicals (EDCs) which are defined as exogenous substances that may provoke changes in endocrine functioning consequentially affecting the health of organism, or its progeny. The hazard of EDCs is due to their ability to interact with human estrogenic receptors, altering in this way the levels of hormones that control growth, reproduction, and development. Damages are not restricted to human beings but to every exposed organisms (Bicchi et al. 2009, Snyder et al. 2003). The low-dose, human beings are exposed to, should not be underestimated since it could cause long-term effects as recently demonstrated by Mersha and collaborators (2015). The exposure to low concentration of bisphenol A (BPA) and bisphenol S during embryogenesis altered adulthood behavior causing neural dysfunctioning (Mersha et al. 2015).

Although it is not clear whether the detected concentrations are high enough to compromise human metabolism, trace levels (from $\mu \mathrm{g} / \mathrm{l}$ to $\mathrm{ng} / \mathrm{l}$ ) have been recognized to be deleterious for the aquatic ecosystem, e.g. for the embryogenesis of fish (Flint et al. 2012, Frye et al. 2011). For example, the 
presence of BPA, equal to or even lower than $1 \mathrm{pg} / \mathrm{l}$, is responsible of hormonal metabolism alteration at different stages of amphibians and fish development (Flint et al. 2012).

EDCs include pesticides, herbicides and fungicides, heat stabilizers, plasticizers, pharmaceuticals, personal care products (PCPs), etc., which derive from many industrial sources as well as the human society daily-life (Frye et al. 2011, Wuttke et al. 2010). Due to their different origin, it is difficult to define a single contamination point, but once entered in the water cycle, wastewater treatment plants (WTPs) are considered to be a clear bottleneck. In many cases the $17 \beta$-estradiol equivalent concentration (EEQ) was significantly higher in the WTPs influents than in rivers. For instance, rivers closed to Shanghai showed EEQ of 2.48-41.9 $\mathrm{ng} / \mathrm{l}$, but this value increased up to 47.7-80.1 ng/l in WTPs influents (Yang et al. 2011). The same was observed in Korean rivers by Ra and collaborators (2011): EEQ contribution of WTPs effluents to river pollution was minimal albeit this was mainly due to a dilution effect and self-depuration of the receiving waters. The actual role and effectiveness of WTPs remained uncertain.

Little information is available about the amount of EDCs, the fate and the effects in municipal sewage wastewaters (Liu et al. 2015, Schilirò et al. 2009). The detected concentration is deeply affected by a number of seasonable factors, mainly uncontrollable and unpredictable as rainfalls, water consumption by the area population, drugs uptake for medical uses, industrial procedures, agriculture practices, etc. (Luo et al. 2014). Besides, many compounds are designed to be chemically and biologically stable (Mompelat et al. 2009), limiting the final efficiency of any treatments. Conventional approaches are not specifically designed to act against EDCs (Bicchi et al. 2009, Luo et al. 2014). Many chemical and physical treatments are adopted by WTPs, but none of them can completely solve the issue of micropollutants (Benotti et al. 2009, Luo et al. 2014). Tertiary treatments as chlorination, ozonation, photocatalytic degradation and adsorption on activated carbons play a more active role in micropollutants removal (Fatta-Kassinos et al. 2011a, Katsigiannis et al. 2015, Lee et al. 2007, Oulton et al. 2010), and particular attention must be given to advanced biological oxidation, which has still room for significant improvements. For example, along the whole WTPs, activated sludge system gave the best degradation yields of BPA (Melcer and Klecka 2011). The possibility to evolve bacterial-based process is still controversial. Among 14 bacterial strains isolated from activated sludge capable of reducing $17 \beta$-estradiol, only one degraded estrone, too (Yu et al. 2007).

Conventional treatments have many drawbacks in terms of energy requirement, large use of chemicals and formation of undesired by-products, which potentially could be even more harmful than the parent ones (Garcia et al. 2011, Reungoat et al. 2010). A clear example is given by a combined $\mathrm{O}_{3} / \mathrm{UV}$ treatment of ketoprofen: the transformation products were much more toxic than 
ketoprofen itself and this parameter could be reduced only by increasing the operational time, with consequent repercussion of the economic sustainability of the process (Illés et al. 2014). Due to the limited effectiveness of WTPs towards a complex mixture of EDCs, micropollutants can re-enter the water cycle accumulating even into drinking waters (Benotti et al. 2009, Lundstrom et al. 2010, Mompelat et al. 2009, Touraud et al. 2011, Vulliet et al. 2011). Sun and collaborators (2013) collected data worldwide, associating the major long-term ecological risk of municipal effluents and reclaimed waters to the presence of steroid estrogens and phenolic compounds. Also agricultures practices are negatively affected by the re-use of still contaminated wastewaters (Fatta-Kassinos et al. 2011b).

Nowadays the removal of emerging contaminants including also but not only EDCs, pharmaceutical, PCPs, etc. from municipal wastewaters represents a social and technological challenge. WTPs are seeking for alternative methodologies, specifically designed to remove micropollutants and to assure the reduction of ecological risk. The public perception is also increasing; therefore a new force is struggling to enhance water quality.

\section{Fungal treatment}

Alternative biological treatments are potentially capable of overcoming the disadvantages of conventional approaches and mediate the efficient removal of micropollutants (Cabana et al. 2007a, Domaradzka et al. 2015). Fungal-based technology rose through years as a perfect candidate to be integrated in WTP process line for the transformation of EDCs and other hazardous emerging pollutants. The coupling of fungi and bacteria for wastewater treatment has already been investigated, reaching the goal to reduce the contaminant content and enhance the water quality for textile wastewaters (Anastasi et al. 2012). So far, this approach has never been investigated yet for municipal wastewaters.

Fungi have long been recognized for their abilities to transform a broad range of recalcitrant compounds through the use of non-specific extracellular oxidative enzymes (Gao et al. 2010, Kaushik and Malik 2009). The idea of using fungi for environmental bioremediation sets its basis in the late 80's (Bumpus and Aust 1987), when a direct connection between the degradation of aromatic compounds and the fungal enzymatic pattern involved in the delignification of wood was hypothesized for the first time.

Having developed a specific mechanism that employs few enzymes and molecules with high oxidizing power, fungi can oxidize aromatic compounds. In particular, oxidoreductases are the most important fungal enzymes involved in the aromatic compounds degradation: laccases (EC 1.10.3.2), peroxidases (EC 1.11.1.x) and peroxigenases (EC 1.11.2.x) are mainly extracellular enzymes. Through years the actual involvement of this various enzymatic pattern has been often 
demonstrated in micropollutants degradation. For instance, effective laccases of Phlebia tremellosa were overproduced by genetic transformation in Irpex lacteus. The much higher laccase expression led to faster and wider conversion of some EDCs such as BPA, nonylphenol (NP) and two phthalates derivate (Kum et al. 2009).

Fungi, and in particular basidiomycetes, have been efficiently used to treat water samples contaminated with micropollutants. Many reports dealt with the removal of recognized EDCs, PCPs, biological active compounds and pharmaceuticals, but the residual toxicity after the fungalbased treatment has been rarely taken into consideration. However where the information related to the chemical composition of the treated samples has been coupled with the toxicity, a more comprehensive assessment of water quality could be obtained. For example, BPA concentration reduction by Stereum hirsutum and Heterobasidium insulare was also associated to estrogenic activity removal (Lee et al. 2005). Trametes versicolor caused the decrease of $99 \%$ of parabens concentration after 2 days, together with a complete detoxification (Mizuno et al. 2009). The great potential of $T$. versicolor strains was also confirmed in the effective removal of two sulfonamides, listed among the most widely used antibiotics (Rodriguez-Rodriguez et al. 2012), ciprofloxacin and norfloxacin (Prieto et al. 2011), and clofibric acid, ibuprofen and carbamazepine (Jelic et al. 2012, Marco-Urrea et al. 2009). Noteworthy among the four tested strains (T. versicolor, I. lacteus, Ganoderma lucidum and Phanerochaete chrysosporium), T. versicolor was the only one capable of converting clofibric acid and carbamazepine with high rates (91\% and 58\%, respectively) (MarcoUrrea et al. 2009).

Comparing data on different fungi, rarely the transformation rate coincides; micropollutants degradation is indeed strictly dependent by the fungal species and even by each specific strain. The importance to work with the proper fungal species is underlined by the high variance of degradation percentage observed by different fungi. Eight basidiomycetes have been used to treat several EDCs from aqueous solution. Even though most of them coupled the effective degradation to the estrogenic activity reduction, a great variability of the process yields was monitored: the fastest and highest transformation was obtained from I. lacteus, Pycnoporus cinnabarinus and T. versicolor (Cajthaml et al. 2009). A different scenario was outlined by a rapid screening, focused on 5 fungi (P. chrysosporium, I. lacteus, G. lucidum, Bjerkandera sp. and Penicillium ochrochloron) and 10 mg/l 17ß-estradiol: 77\% and 99\% removal was obtained by P. chrysosporium and G. lucidum, respectively (Blanquez and Guieysse 2008).

Besides, the use of specific strain seemed to be important as well. For example, two distinct studies set up a fungal screening for NP removal using some common species allowing to compare the obtained results. It should be mentioned that a different substrate concentration was used: $3 \mathrm{mg} / \mathrm{l}$ 
(Cajthaml et al. 2009) and $100 \mathrm{mg} / \mathrm{l}$ (Soares et al. 2006). This did not bother the strains of $T$. versicolor and Bjerkandera adusta used in the two studies which showed a comparable behavior in term of both substrate removal $(100 \%)$ and timing ( 2 weeks). As regard the other tested strains, data did not always correspond, e.g. P. chrysosporium: the yields ranged from $100 \%$ after 7 days (Cajthaml et al. 2009) to 50\% after 25 days (Soares et al. 2006).

Up to date most of the researches deal with synthetic and simplified solutions, using single molecules at high concentration and controlling operative conditions, e.g. pH. However a sterile and controlled environment gives weak information about the capability of the fungus to grow and remain active in very variable and restrictive conditions of real municipal wastewater (several micropollutants at low concentration, suspended solids, competing with the autochthonous microflora, etc.). Moreover, working at high pollutants concentration (above mg/l), the acquired information is poorly predictive of the fungal performances on real water samples (Blanquez and Guieysse 2008, Cajthaml et al. 2009). The applied substrate concentration should be as much as possible close to environmentally relevant ones $(\mu \mathrm{g} / \mathrm{l}-\mathrm{ng} / \mathrm{l})$. Noteworthy Trametes hirsuta halved the initial amount of 9 out to 17 pharmaceuticals set at realistic concentrations (20-500 ng/l) (Haroune et al. 2014). The removal of naproxen and diclofenac by $T$. versicolor was almost complete at $10 \mathrm{mg} / 1$ and at 45-55 $\mu \mathrm{g} / 1$ (Marco-Urrea et al. 2010a, Marco-Urrea et al. 2010b).

Only few researches have used real wastewaters, facing harsh working conditions that can be found in WTPs, ultimately able to negatively affect fungal growth and EDCs removal. Hospital and municipal wastewaters have been treated, obtaining positive responses by T. versicolor and $P$. chrysosporium (Ferrando-Climent et al. 2015, Jelic et al. 2012, Zhang and Geißen 2012). Interestingly, a waste landfill leachate was successfully treated by $T$. versicolor and $S$. hirsutum that combined adsorption and biodegradation mechanism. BPA, NP, ethynilestradiol, dimethoate and linuron were detected in the sample and used as target analytes. With only exception of dimethoate (at least 60\%), the removal was complete for T. versicolor. S. hirsutum gave optimal response only for NP $(100 \%)$, whereas the other compounds were converted at a lower extent (30-80\%). It should be considered that the addition of synthetic nutrients in the form of potatoes dextrose medium was always necessary to sustain an active fungal mycelium (Castellana and Loffredo 2014).

Talking about industrial scale feasibility of a process, the set up and the validation of a proper reactor configuration is mandatory. Efforts aimed to develop fungal bioreactors have been made but mostly addressed to textile wastewaters treatment (Anastasi et al. 2010, Baccar et al. 2011, Novotny et al. 2011).

One of the first reports about the scaling up of micropollutants treatment from flasks was carried out by Blanquez and Guieysse (2008) who set up a small air fluidized bioreactor with free biomass of $T$. 
versicolor. The system continuously operated for 26 day, completely removing $17 \beta$-estradiol and $17 \alpha$-ethinylestradiol by expressing solely laccase activity (156 U/1).

A plate reactor was run with $P$. chrysosporium mycelium immobilized on polyurethane foam under non-sterile conditions (Zhang and Geißen 2012). Carbamazepine (5 mg/l) was efficiently eliminated by means of the combination of biodegradation and biosorption mechanisms: after the first 3 batches, process yields sensibly lessened at the $4^{\text {th }}$ batch (from $20 \%$ to $55 \%$ of residual concentration). Feeding up the system with real municipal wastewaters, carbamazepine elimination was around $60 \%$ and the reactor could run for 100 days, but an adequate nutrients addition was necessary (Zhang and Geißen 2012). A lower concentration of carbamazepine was treated by $T$. versicolor in batch $(200 \mu \mathrm{g} / \mathrm{l})$ and continuous $(11.9 \mu \mathrm{g} / \mathrm{g}$ dry weight pellets per day) treatment in an air pulsed fluidized bed bioreactor (Jelic et al. 2012).

Immobilized $P$. chrysosporium was used to set a countercurrent seepage bioreactor for the treatment of a synthetic wastewater spiked with naproxen and carbamazepine: no bacterial contamination was observed in 165 days even though sterility was not controlled. Thanks to the comparison with other configurations (i.e. submerged mode reactor), it could be stated that the degradation percentages (80-100\%) were reached with the specific working conditions applied (Li et al. 2015).

Noteworthy, hospital wastewaters containing 43 pharmaceutical active compounds and 46 EDCs have been treated by a fluidized bed reactor with T. versicolor (Cruz-Moratò et al. 2014). The vitality of the fungus even in axenic conditions was indicated by the immediate consumption of the added glucose and the production of 320 U/1 laccases. However, without any sterility control, the treatment did not last more than 5 days, when a massive bacterial development was observed and coupled with fungal biomass disaggregation.

Although the ability of fungi to degrade emerging contaminants has found many confirmations in the last decades, their involvement along WTPs has not found a clear confirmation so far. One of the main limits of biological treatment based on living organisms consists indeed in the requirements of specific and controlled operative conditions, in order to maintain a durable and efficient system. Besides fungi are influenced by chemical-physical parameters as well as by the culturing conditions: nutrients presence, $\mathrm{pH}$ values, immobilization on different supports, agitation/static growth conditions can deeply affect the fungal oxidative metabolism (Kaushik and Malik 2009).

So far, fungal-based processes need to be transferred from lab scale to industrial level working with real municipal wastewaters. Process developments are still necessary to achieve the technical and economic feasibility of fungal treatments. The optimization of chemical-physical parameters (e.g. nutrients addition, $\mathrm{pH}$, etc.) and technological features (e.g. carrier selection, design of proper 
reactor configuration, etc.) would allow setting up a whole-cell fungal treatment in WTPs, synergically working with already existing techniques to reduce micropollutants concentration and toxicity.

\section{Enzymatic treatment}

In this context, a new environmentally friendly technology for industrial biotransformation, with low costs and low consumption of resources, could be very competitive. A promising alternative could be represented by the direct use of fungal crude extract or by purified enzymes capable of maintaining the catalytic yields of the fungal cultures, with less technical drawbacks (Torres et al. 2003). The use of purified enzymes poses some concerns for environmental purposes; without other enzymatic isoforms and fungal metabolites, their catalytic efficiency and stability could be compromised. Complex matrixes as municipal wastewaters claim instead for robust, versatile and effective systems that can be guarantee by heterogeneous enzymatic fungal extracts.

The potential of enzymes-based methods has been recognized worldwide; to this regard, the Swiss Industrial Biocatalysis Consortium defined oxidative enzymes as the biocatalysts displaying the highest development potential in the next decades (Meyer and Munch 2005). Considerable importance is given to the discovery of novel stable enzymes with wide substrate specificity and industrial potential.

\subsection{Fungal peroxidases}

Peroxidases include several enzymatic classes found in many fungi: lignin peroxidase (EC 1.11.1.14) and manganese peroxidase (EC 1.11.1.13) were found for the first time in $P$. chrysosporium (Glenn and Gold 1983, Tien and Kirk 1983), versatile peroxidase (EC 1.11.1.16) was described in Pleurotus and Bjerkandera genera (Martinez et al. 2002), and dye-decolorizing peroxidase (EC 1.11.1.19) was observed in Auricularia auricula-judae and Pleurotus ostreatus (Faraco et al. 2007, Liers et al. 2010). The expression of these enzymes is not constitutive and depends on the external conditions. Response elements to the presence of xenobiotic molecules have been found on the promoters of the genes coding for lignin peroxidase, while manganese peroxidase and versatile peroxidase are regulated by the presence of metals and thermal stress (Heinfling et al. 1998, Martınez-Martınez 1996).

Besides conventional pollutants, research demonstrated the potential of peroxidase against emerging contaminants. For example, both analytes concentration (octylphenol, BPA and estrogens in buffer solution) and toxicity were reduced by lignin peroxidases from Phanerochate sordida (Wang et al. 2012).

Peroxidases generally show a higher redox potential than laccases, allowing a clear catalytic advantage. Manganese peroxidase from $P$. chrysosporium was able to totally degrade triclosan 
(TCS), while the best performance of laccases from $T$. versicolor (33.9\% residual TCS) was obtained only in presence of hydroxybenzotriazole (HBT) as mediator and double enzymatic concentration (Inoue et al. 2010). Similarly, carbamazepine depletion was closed to 14\% with manganese peroxidase and almost null with laccases alone. Laccases efficiency was significantly enhanced (22\%) only in presence of mediators (Hata et al. 2010).

The main restriction of haem containing enzymes is their poor stability to environmental conditions and reaction products as well as rapid deactivation of hydrogen peroxide (Buchanan and Han 1999, Buchanan and Nicell 1998, Gasser et al. 2012). Even in model, sterile and buffered solutions, 90\% of lignin peroxidase activity was lost after 24 hours (Wang et al. 2012). Enzyme inactivation was the major drawback of the treatment of 5 EDCs by an innovative approach based on the high reactive oxidants (i.e. $\mathrm{Mn}^{3+}$-malonate complex) produced by peroxidases of $B$. adusta (TaboadaPuig et al. 2015). In particular, in the versatile peroxidase catalytic cycle, $\mathrm{Mn}^{3+}$-malonate complexes are usually formed to stabilize the oxidized $\mathrm{Mn}$ ion and propagate the oxidative reaction. The continuous production of the complex was not possible because of peroxidase inactivation. The authors overcame the problem by designing a two-stage system (complex formation and then EDCs degradation) enhancing the system stability up to 8 hours (Taboada-Puig et al. 2015).

At the present state of art, these factors ultimately prevent the use of peroxidase-based technologies at WTP level. On the contrary, since laccases use oxygen as final electron acceptor, they are not negatively influenced by peroxide deactivation but they need a sufficient aeration.

\subsection{Fungal laccases}

Laccases (EC 1.10.3.2) have been pointed out as green catalysts, which work with air, producing water as the only by-product (Riva 2006). Laccases are glycosylated multicopper oxidases whose production is barely constitutive in fungi; gene transcription is regulated by metal ions, various aromatic compounds related to lignin, nitrogen and carbon: all these factors act synergically, stimulating laccase production (Piscitelli et al. 2011). Moreover, laccase stability in a wide range of chemical-physical condition makes them good candidates to be used as biocatalysts for industrial purposes (Riva 2006).

The involvement of laccases in the oxidative cascade triggered by fungi has been confirmed by observations of fungal behavior in presence of micropollutants: fungi often respond to these chemicals by stimulating the enzymes production and secretion. Agrochemical and industrial pollutants strongly induced the production of laccases in T. versicolor (Mougin et al. 2002). A similar induction was noticed after phthalates, BPA and NP addition to a $T$. versicolor culture: the secreted enzymatic pattern further degraded the molecules tested (Kim et al. 2008). Cheong and collaborators (2006) monitored the expression levels of laccase genes in $T$. versicolor during the 
treatment of 2,4,6-trinitrotoluene. The higher gene expression in the cultures containing the substrate in comparison with the control (no substrate) demonstrated the actual involvement of laccases.

Laccases extracts from different fungi (e.g. T. versicolor, Coriolopsis gallica, Cerrena unicolor, G. lucidum, Myceliophthora thermophila, etc.) have been tested on several well-known micropollutants such as BPA, NP, TCS, carbamazepine, antinflammatory pharmaceuticals and estrogens (Auriol et al. 2008, Kim and Nicell 2006a, Lloret et al. 2010, Lloret et al. 2012a, Lloret et al. 2013, Murugesan et al. 2010, Songulashvili et al. 2012, Torres-Duarte et al. 2012, Tran et al. 2013). Transformation rates of many compounds were not always coherent among evidences present in literature. This could be explained looking at the intrinsic biochemical and catalytic properties (e.g. structure of the active site and the region nearby, redox potential, etc.) of each laccase, which depend on to the fungal strain they have been produced from. Any laccase isoform has indeed the potential to differently interact with a substrate. For instance NP was not a substrate for laccases from Phoma sp. whereas $90 \%$ of removal was achieved by laccases form P. ostreatus. On the contrary the two laccases crude extracts did not show significant variation treating BPA and 17 $\alpha$-ethinylestradiol (Libardi Junior et al. 2012). These evidences suggest that an enzymatic treatment could be based of different enzymes, each of them with its own peculiarity in terms of substrate spectrum, substrate affinity, optimal working conditions (e.g. pH), etc. A multi-enzymatic approach could thus enlarge the range of target compounds and the working conditions compared to single-laccase systems, because the enzymes complete each other. Amman and collaborators (2014) deepened this assumption, co-immobilizing laccases of Thielavia sp., Coriolopsis polyzona, $C$. unicolor, $P$. ostreatus and $T$. versicolor on silica nanoparticles. Noteworthy the co-immobilization of Thielavia sp. and P. ostreatus laccases led to a wider operative $\mathrm{pH}$ range: the recovery of $70 \%$ of the activity between pH 3 and 7 was never possible in presence of the single-laccase solutions. As regard the substrate affinity, C. polyzona and T. versicolor laccases worked better together than alone: the multi-enzymes system converted the 5 compounds tested, including benzophenone- 2 and gemfibrozil which were never oxidized by C. polyzona and T. versicolor laccase, respectively (Amman et al. 2014). The development of this technology could take into consideration also the coimmobilization of different enzymes typology e.g. as laccases and cytochrome P450 which played both an active role in the conversion of diclofenac and naproxen by $T$. versicolor (Marco-Urrea et al. 2010a, Marco-Urrea et al. 2010b).

Besides the transformation rate of single-compound and mixture solutions can deeply vary. Indeed some molecules and/or the products of their partial degradation can act as radicals and propagate the laccase oxidation towards the other micropollutants. The responses given in the presence of 
single-compound and mixture solutions do not usually correspond. The substrates themselves and their products could influence the oxidation one to another; effects could not a priori predict. Diclofenac oxidation (25\%) was enhanced in the presence of BPA $(60 \%)$ and mefenamic acid (95\%). On the contrary, the presence of diclofenac decreased BPA and mefenamic acid conversion probably due to competition phenomena for the active site (Margot et al. 2013).

Estrogens, phthalate, pyrene and several phenols derivates $(20 \mathrm{mg} / \mathrm{l})$ were treated by crude laccase extracts from $T$. hirsuta, Trametes orientalis, $T$. versicolor and P. coccineus. With the exception of phthalate and pyrene, the micropollutants were concurrently almost completely (90\%) removed (Sei et al. 2008). Eighteen EDCs, pharmaceuticals and PCPs with known or suspected estrogenic activity were treated by laccases from Trametes pubescens: high removal efficiency $(>60 \%)$ was achieved for 13 compounds (Spina et al. 2015).

\subsubsection{Laccase mediated system}

Laccases-catalyzed oxidation includes two distinct paths: the direct interaction with the active site and/or the propagation of the oxidation cascade by means of small molecules which diffuse and act towards the target substrates. These low-molecular weight compounds enlarge the spectrum of the potential substrates of laccases, increasing the low redox potential $(0.5-0.8 \mathrm{~V})$ up to $1.3 \mathrm{~V}$. The laccase mediated system oxidizes non phenolic molecules as well as compounds which, due to their size and steric hindrance, cannot be oxidized by laccases at their own (Canas and Camarero 2010, Desai and Nityanand 2011). Many natural mediators produced by the fungal mycelium and synthetic compounds have been evaluated for their capability to propagate the laccases oxidative cascades: at the moment, more than 100 molecules have been analyzed (Desai and Nityanand 2011). The use of 2,2'-azino-bis(3-etilbenzotiazolin-6-sulfonico) (ABTS), HBT, veratryl alcohol, cathecol, syringaldazine, TEMPO, etc. have been often coupled with laccases, greatly enhancing the final oxidation rate (Desai and Nityanand 2011). The strength of the propagated oxidation cascade depends also on the laccase-mediator interaction. The mediators should have a high affinity for the laccase isoform and not interfering with the enzyme active site. Once oxidized, they should be stable and capable of reducing back to their initial form to enter again in the enzymatic catalytic cycle (Morozova et al. 2007).

In many cases, no reactions were observed by laccases alone, making mediators addition mandatory. This phenomenon was true for very recalcitrant compounds as the herbicide dymron (Maruyama et al. 2006) and halogenated pesticides (Torres-Duarte et al. 2009).

ABTS and HBT are among the most studied compounds, which are capable of micropollutants conversion in several case studies (Cabana et al. 2007a). The presence of ABTS enhanced transformation of dymron (Maruyama et al. 2006), TCS (Kim and Nicell 2006a), sulfonamide 
antibiotics (Weng et al. 2013), BPA (Kim and Nicell 2006b, Macellaro et al. 2014) and parabens analogues (Macellaro et al. 2014). On the other side HBT was found to be fundamental during laccase treatments of carbamazepine (Hata et al. 2010), iso-butylparaben and $n$-butylparaben (Mizuno et al. 2009), anti-inflammatories and estrogens (Lloret et al. 2010) and tetracycline antibiotics (Suda et al. 2012).

Among 4 mediators used to trigger BPA and TCS oxidation by two batches of laccases, ABTS resulted to be the best one (Arboleda et al. 2013). The role of guaiacol, veratryl alcohol and HBT depended on the used laccase batch, highlighting the strict connection between laccase isoform, mediator and target substrate (Arboleda et al. 2013). In agreement with this, laccases from another fungus (G. lucidum) achieved higher reduction yields in presence of HBT and syringaldehyde rather than ABTS (Murugesan et al. 2010).

In particular dimethoxy substituted phenols like syringaldehyde and acetosyringone have a low redox potential favoring their activation as mediators by laccase initial oxidation. They were responsible for strong pesticides transformations, which could be even 100-fold higher than TEMPO-mediated reactions (Torres-Duarte et al. 2009). As regards TCS conversion, laccases of $G$. lucidum better responded to syringaldehyde than HBT (Murugesan et al. 2010).

Even considering the great catalytic benefits of a laccase-mediator system, the use of synthetic mediators remains a highly controversial subject. A detailed evaluation of risks and benefits is necessary carefully considering several factors: mediators have a cost, may be toxic and need to be regenerated in the system, too (Kunamneni et al. 2008, Torres 2003). Moreover, in some cases, the oxidized radicals can destabilize the enzymes, leading to irreversible inactivation (Kunamneni et al. 2008). As an example, $3 \mathrm{mM}$ syringaldehyde inhibited the catalytic activity of Trametes trogii laccase, whereas vanillin and coumarate did not (Khlifi-Slama et al. 2012). A high loss of activity (67\%) was observed in presence of TCS and HBT (Murugesan et al. 2010). the use of crude extracts may be preferred to purified enzymes, since they are cheaper and may be more efficient due to the presence of natural mediators and several soluble molecules able to improve the catalytic efficiency and stability (Levin et al. 2010, Majeau et al. 2010, Morozova et al. 2007, Strong and Claus 2010).

\subsubsection{Effect of reaction conditions on micropollutants degradation}

Technical feasibility of enzymes-based treatments is still a challenge. Enzymes can be destabilized by the real chemical-physical conditions of municipal wastewaters, limiting the possibility to hypothesize a new treatment line in the framework of WTPs. Moreover, the operative parameters can affect conversion rates and can completely switch off the system. For example, $\mathrm{pH}$, temperature, loaded enzymes concentration and contact time greatly affected (ranging from 0 to $100 \%$ ) the removal of 4 EDCs (Margot et al. 2013). 
In detail $\mathrm{pH}$ has a major role in enzymes performances. Laccase-catalyzed system was studied over a $\mathrm{pH}$ range 5-9 and set at 6 for natural estrogens (estrone, 17 $\beta$-estradiol and estriol) and synthetic estrogen (17a-ethinylestradiol) (Auriol et al. 2007). The optimal $\mathrm{pH}$ range of 4-6 was observed for the transformation of dymron (Maruyama et al. 2006), TCS (Kim and Nicell 2006a, Margot et al. 2013), sulfonamide antibiotics (Weng et al. 2013), anti-inflammatory pharmaceuticals (Margot et al. 2013) and BPA (Kim and Nicell 2006b, Margot et al. 2013).

A factorial design was used to describe the optimal working conditions in terms of $\mathrm{pH}$, temperature and treatment time for the transformation of BPA and TCS by laccases of two forest fungi, Ganoderma stipitatum and Lentinus swartzii (Arboleda et al. 2013). The reaction was maximal at $40-60^{\circ} \mathrm{C}$ and $\mathrm{pH} 5$, in accordance with other data available in literature. Nonylphenol and TCS were degraded by laccases from C. polyzona at $50^{\circ} \mathrm{C}$ and $\mathrm{BPA}$ at $40^{\circ} \mathrm{C}$; acidic environment (pH 5) was optimal for the three micropollutants (Cabana et al. 2007b).

Thermotolerant enzymes should be considered separately. As an example, the best working temperature for laccases of Trametes sp. was $70^{\circ} \mathrm{C}$, which sharply decreased of 5 -fold at $30^{\circ} \mathrm{C}$ (Maruyama et al. 2006). New industrial scenario where fungal thermotolerant laccases could be exploited arises, but it should be carefully taken into consideration the WTP localization and working temperature along the plant.

Operative setting parameters (i.e. loaded laccase concentration, substrate frequency addition, aeration) can play a key role. The control of the effective laccase amount is important to constrain economic feasibility of the process. The use of highly concentrated enzymatic solution does not necessary reflect better conversion yields. For example, the treatment of estrone and estradiol was carried out with laccases from $M$. thermophile using up to 2,000 U/1. The minimal effective enzymatic concentration was found to range from 100 to $500 \mathrm{U} / 1$ with no mediator need (Lloret et al. 2012a). These values are coherent with those observed by Spina and collaborators (2015): in the tested range (10-500 U/1) the minimal effective concentration for 18 compounds was usually 100 U/1. Much higher activities (2,000-20,000 U/1) were analyzed by Auriol and collaborators (2007): laccases from $T$. versicolor achieved the complete removal of natural estrogens (estrone, $17 \beta$ estradiol, estriol) and a synthetic estrogen (17 $\alpha$-ethinylestradiol) but mediators were required. The use of the highest $(20,000 \mathrm{U} / 1)$ investigated concentration was justified by the fact that $100 \%$ conversion was obtained without mediator use (Auriol et al. 2007).

Oxygen cannot be surely wanting from the aqueous solution, claiming for controlled dosage and developed supply technologies. Continuous aeration is not always the best methodology to be applied since batch pulses can sustain the biological oxidation, reducing of course cost and energetic requirements (Lloret et al. 2012b). In a continuous enzymatic membrane reactor 
oxygenation rate was set as a response parameters, as well as enzyme activity and hydraulic residence time. Estrone, estradiol, and ethinylestradiol removal was maximal (71-81\%) at 1,000 U/1 of laccase, 1 hour and $60 \mathrm{mgO}_{2} /$ h of oxygenation rate (Lloret et al. 2013).

The industrial feasibility of any enzymatic treatment undergoes through fast processes, able to integrate into WTPs where hundreds of $\mathrm{m}^{3}$ of water flux every day. As a consequence, operational time is an important parameter to set. Laccases are optimal biocatalysts and mediate reactions that usually last from minutes to few hours: 4-6 hours are needed for the treatment of TCS, BPA and parabens (Arboleda et al. 2013, Mizuno et al. 2009). A commercial laccases was rapid converting estrogens (15 min), but was much slower ( 8 hours) for more recalcitrant compounds such as naproxen (Lloret et al. 2010). These data acquire great importance if referred to municipal wastewaters. Oxybenzone removal required 2 hours (Garcia et al. 2011), whereas 20,000 U/1 completely removed estrogens in a wastewater sample within a 1 hours (Auriol et al. 2008). The half-life was lower than 4 hours for 10 up to 18 micropollutants, and most of these occurred in the first minutes of the treatment (Spina et al. 2015).

\subsubsection{Laccases stability}

Although fungal enzymes are known to operate in a wide $\mathrm{pH}$, temperature and ionic strength range, the harsh conditions of municipal wastewaters may affect the enzymatic catalytic efficiency and stability. The presence of organic compounds was found not able to influence laccase activity (Kim and Nicell 2006b). Several salts were also considered leading to the observation that ions can affect laccases performance, e.g. cyanide by direct interaction with the active site and further dissociation of the $\mathrm{Cu}$ ion. The cations $\mathrm{Na}^{+}, \mathrm{Mg}^{2+}$ and $\mathrm{NH}^{4+}$ and the anion $\mathrm{SO}_{4}{ }^{2-}$ did not interfere contrarily to $\mathrm{Cl}^{-}$. Several chlorine ion forms $\left(\mathrm{NaCl}, \mathrm{CaCl}_{2}, \mathrm{MgCl}_{2}\right.$ and $\left.\mathrm{NH}_{4} \mathrm{Cl}\right)$ were investigated resulting in a similar effect on enzymatic activity. This observation would need deep reflections, mainly in those WTPs that use chlorination as fine tertiary treatment and then present residual chlorine ions traces in the effluent to be treated.

The inactivation of the enzymes of interest could be reduced by the presence of additives capable of interacting with the enzyme and/or the reaction products, as demonstrated by Kim and Nicell (2006c). Polyethylene glycol (PEG), polyvinyl alcohol and the branched hydrophilic polysaccharide Ficoll were applied during BPA transformation by laccases from $T$. versicolor highlighting the great potential of PEG. Unfortunately the toxicity monitored by means of Vibrio fisheri increased due probably to the formed products which solubility was enhanced by the presence of PEG. These results clearly indicated that innovative solutions and process developments could and should be searched, looking at the system efficiency as a whole. 
A feasible approach considers the enzymatic immobilization in specific supports, in order to protect the enzymes from denaturing agents: in optimized conditions, the system may remain stable for a long time and enzymes may not be released in the environment (Desai and Nityanand 2011, Gasser et al. 2014a). Moreover, this technology allows the regeneration and reuse of the biocatalysts avoiding their washing out along a continuously operating WTP. Inert materials are often preferable, avoiding micropollutants adsorption, enzymatic activity alteration and toxic effects.

A number of materials complied these requirements, successfully supported laccases for micropollutants removal: nylon membranes (Diano et al. 2007), silica particles (Gasser et al. 2014b, Songulashvili et al. 2012), Eupergit carriers (Lloret et al. 2012a), $\mathrm{TiO}_{2}$ nanoparticles (Hou et al. 2014), glass beads (Macellaro et al. 2014) and cross-linked enzyme aggregates (Cabana et al. 2007c) among others.

The selection of carriers manageable for industrial purposes and capable of maintaining enzymes stability and functions as long as possible is a crucial point. Thermostability is generally the first parameter on which immobilization could have positive effects. The half-life at $70^{\circ} \mathrm{C}$ of immobilized laccases on silica beads was 3-fold higher than free enzymes, and they maintained at least the double of activity during the exposure at high temperature as $80^{\circ} \mathrm{C}$ (Songulashvili et al. 2012). Laccases on polyacrylonitrile beads achieved great advantages in terms of $\mathrm{pH}$ and thermal stability during bisphenol analogues conversion (Nicolucci et al. 2010). A fluidized bed reactor was set up achieving up to $85 \%$ activity recovery of immobilized laccase after 30 days.

Besides, chemical resilience could be provided by optimized immobilization techniques. Laccases immobilized on isocyanate-terminated prepolymers efficiently transformed few EDCs (TorresDuarte et al. 2012). Covalent binding of enzymes on diatomaceous earth support was a suitable solution, able to guarantee high laccases recovery in presence of several denaturants (acetone, methanol, EDTA, $\mathrm{CaCl}_{2}$ ) and the enhancement of the catalytic activity (Cabana et al. 2008). The bio-construct worked continuously over five cycles.

In some cases this technology could even foresee the increase of the initial laccase activity (Gasser et al. 2014b, Hommes et al. 2013). Noteworthy, the immobilization of laccase from Thielavia on silica nanoparticles was carried out at kilogram scale, the laccase activity recovery significantly increased (132.5\% higher than the loaded activity) (Gasser et al. 2014b). The designed membrane bioreactor was used to treat municipal effluents (BPA as target analyte): 66\% degradation was followed by a significant enzymatic loss (30-40\% recovery). Besides, the process effectiveness was evaluated not only in term of chemical conversion but a detailed economic balance was also performed. Enzymatic treatment resulted technical and economic competitive with other tertiary wastewater treatments (ozonation and PAC adsorption). In accordance to these findings, membrane 
reactors have been proven suitable reactor configurations for micropollutants removal (Lloret et al. 2013, Nguyen et al. 2014).

\subsubsection{Laccases vs municipal wastewaters}

The inactivation of free laccases was relevant when challenged to treat real municipal wastewaters. The heterogeneity of their composition includes reducing anions, organic solvents, heavy metals, cyanide, salts and suspended particles, which, coupled with potentially toxic products of EDCs oxidation pathway may interfere with enzymatic catalytic activity and stability. Most of the activity (54\%) was lost after 24h-treatment of municipal wastewater (Spina et al. 2015) and the same effect was observed by Tran and collaborators (2013) who reported that $30 \%$ of laccase activity was lost in only 4 hours.

A preliminary indication of the actual laccases potential is given by real water matrix spiked with targeted analytes. Groundwater samples were supplemented with BPA, NP, TCS and $17 \alpha-$ ethinylestradiol: the slightly minor process yields were charged to the presence of ions that may inhibit laccase activity (Garcia-Morales et al. 2015). Estrogens depletion in municipal waters was worse than in spiked solutions using 2,000-10,000 U/1 of laccases from T. versicolor (Auriol et al. 2007). No differences were observed in presence of higher loaded biocatalysts.

These observations are not necessary translated in an ineffective treatment. With the only exception of 2,4-dichlorophenol and BPA, 7 emerging contaminants including biological active compounds as pharmaceutical, pesticides and herbicides, were converted at high extent (above $72 \%$ ) by laccases from T. pubescens (Spina et al. 2015). The toxicological analysis provides the final evidence about the enhanced water quality after the treatment. Commercial fungal laccases worked also on the insect repellent N,N-diethyl-m-toluamide detected in a real wastewater (Tran et al. 2013). It is interesting to notice that degradation rates were higher in real conditions than in model ones. A possible explanation could be given by the presence of phenolic compounds in real waters that may act as natural mediators trigging laccase-mediated oxidation to higher extent. Laccase-based system oxidized personal and pharmaceutical care products (oxybenzone as target analyte) from municipal wastewater primary effluent: laccase mediated system achieved complete removal even in harsh real conditions, but enzymes activity was negatively influenced by the wastewater matrix (Garcia et al. 2011).

Only few studies took into consideration environmentally relevant concentration of micropollutants (few $\mu \mathrm{g} / \mathrm{l}$-ng/l) where indeed laccases may be limited by substrates diffusion and contact time. Those enzymes capable of working in these conditions deserve particular attention. Laccases of $T$. versicolor led to the same results (100\% removal of oxybenzone) at high (1,000 $\mu \mathrm{g} / \mathrm{l})$ and low (10 
$\mu \mathrm{g} / \mathrm{l})$ (Garcia et al. 2011). Laccases of $T$. pubescens effectively treated a municipal wastewater containing 9 micropollutants at a concentration of 0.13 to $67.6 \mu \mathrm{g} / 1$ (Spina et al. 2015).

Advanced in silico technologies open new perspective in this field, clarifying how a certain process could evolve to reach industrial application. To this regard, an intriguing mathematical model was run to describe the behavior of enzymatic membrane reactor in presence of effluents containing tetracycline (Abejon et al. 2015). A large-scale system based on commercial laccases immobilized on ceramic membranes was designed to implement WTPs in three different case-studies (municipal, hospital and industrial plants). The results for the municipal WTP indicated that $300,000 \mathrm{~m}^{2}$ of membrane would be needed, meaning 590,000 membrane modules. The technical feasibility was demonstrated but the authors stated that additional analyses are required to enhance the competitiveness of the enzymatic process.

\section{Toxicity evaluation}

The scenario drawn by the presence of emerging contaminants in water bodies is difficult to define, ultimately limiting the assessment of traditional and innovative treatments effectiveness. Trace levels (from $\mu \mathrm{g} / \mathrm{l}$ to $\mathrm{ng} / \mathrm{l}$ ) and the heterogeneity of chemical composition make water risk assessment a true challenge.

First, their detection appears to be strongly influenced by the available analytical techniques, rarely capable of detecting traces of chemicals (Lundstrom et al. 2010, Mompelat et al. 2009, Snyder et al. 2003, Touraud et al. 2011). In 2001, EPA pointed out the lack of sensible and standardized methods for EDCs detection and, at the moment, a dedicated institution, the Endocrine Disruptor Methods Validation Subcommittee, is working to fill this void (Snyder et al. 2003). The identification of EDCs in real water matrixes cannot be taken for granted; routine monitoring programs cannot give a complete chemical characterization of the out-put waters from a municipal WTP. The occurrence of some target compounds is a first step but it cannot clearly state whether or not water is safe. Canadian Environmental Protection Act (1999) listed more than 132 molecules, stating that they could alter the biological diversity and affect human health; among them only two (NP and nonylphenol ethoxylates) are recognized EDCs.

Further investigation on the biological effects of the released treated effluents is necessary to set water quality protocols and endeavor regulatory limits to follow. A complete understanding of the biological effect of mixed substrates is necessary, considering synergistic or antagonistic interactions among chemical substances. A mixture of compounds is usually more toxic than expected by summing the effects of each single component (Soupilas et al. 2008). Toxicological analysis by biological assays takes into account the whole effluent being a powerful toolbox for the risk evaluation of such complex wastewaters. The long-term ecological hazard associated to the 
release of municipal wastewaters into the environment found many proofs, allowing the definition of many dangerous chemicals and justifying the request to introduce bioassays as standard procedure for water quality control (Leusch et al. 2014, Mendonca et al. 2009). Three bioassays with organisms belonging to different trophic levels (algae, zooplanktons, bacteria) highlighted the toxicity of ketoprofen and its derivates (llés et al. 2014). The algae Raphidocelis subcapitata, formerly known as Pseudokirchneriella subcapita, was highly sensible to aquatic toxicity of the Sava River, in the Balkans area (Kallqvist et al. 2008). A pan-European screening on 75 WTP effluents has been carried out by MELN gene reported assay, indicating that most of them present not negligible estrogenic effects (Jarošová et al. 2014a).

Two sides of the same concept need focused analysis. Micropollutants may have deleterious effects at different stages of the life of any microorganisms, being the hormone mimicking only one of the metabolic mechanisms that could be enrolled by pollutants. High quality waters claimed for ecotoxicity evaluation and estrogenic potential as well. The major issue is still associated to missing data about the hazard of thousands of chemicals and the uncertainty of the connection exposureeffect (Fuhrman et al. 2015).

Several bioassays have been assessed for estrogenic activity evaluation but only few of them are standard procedures. The major drawback is their sensibility to micropollutants typology and concentration commonly found in municipal wastewaters. Though EDCs affinity to human estrogen receptor is lower than the human estrogen $17 \beta$-estradiol, some micropollutants as BPA, NP and TCS gave positive responses (Torres-Duarte et al. 2012). The affinity decreased after the laccase treatment and the same profile was observed in vivo experiments with zebrafish (Torres-Duarte et al. 2012). The use of animal-based methods has been largely developed through years, being at the base of Endocrine Disruptor Screening Program of EPA. Two-tiered testing program (Tier 1 and 2) has been planned, including in vitro (non-animal cell lines) and in vivo (animal) approaches. (Bishop and Willett 2014) The goal is to assess the capability of more than 10,000 chemicals to give negligible effects on human endocrine systems. However, the use of the developed animal-based assays for routine monitoring of environmental samples poses at first ethical problems that could not underestimated (Purchase 1999).

Easy to perform and reliable in vitro tests became attractive solutions. Since their potential to describe estrogenicity is at least different from in vivo methodologies, their prediction potential and limits should be carefully evaluated (Jarošová et al. 2014b). Among the others, yeast estrogen screen assay (YES) is a well-known test able to evidence the estrogenic activity inherent to water samples monitoring the toxicity profile before and after laccase-based treatments (Arboleda et al. 2013, Chou et al. 2015, Mizuno et al. 2009). The human breast cancer cell line (MCF-7 BUS) 
proliferation test (E-screen test) and the luciferase-transfected human breast cancer cell line gene reporter assay (MELN assay) have been successfully used to monitored estrogenicity through biological treatments (Lee et al. 2007, Spina et al. 2015).

Many reports included a single test to assess the water quality. Luminescent bacteria $V$. fischeri (UNI EN ISO 11348-3) was used for the conversion of NP by 4 fungi (Soares et al. 2006), BPA and TCS by laccases from T. versicolor (Kim and Nicell 2006c), sulfonamide antibiotics by laccases from Perenniporia sp. (Weng et al. 2013), naproxen (Marco-Urrea et al. 2010b) and several pharmaceuticals and recognized EDCs by laccases from T. versicolor (Cruz-Moratò et al. 2014). Inhibition of $R$. subcapitata growth (UNI EN ISO 8692: 2005 method) was followed in the presence of tetracycline antibiotics (Suda et al. 2012). YES assay was used to evaluate the estrogenic activity of parabens (Mizuno et al. 2009) and estrogens in municipal wastewaters (Auriol et al. 2008). Methods based of human breast cancer cell line (i.e. MELN assay and E-screen test) have been performed to evaluate the actual risk associated to bisphenol treated by two lignindegrading basidiomycetes (Lee et al. 2005) or a complex mixture of micropollutants (Spina et al. 2015).

However, the sensitivity of each test species depends upon the chemical composition of the sample, and a toxic effect could be detected or not by different model organisms. A battery of ecotoxicological tests is recommended, using organisms preferentially belonging to different trophic levels (Soupilas et al. 2008, Tigini et al. 2011). For instance, estrogenic activity of NP and octylphenol treated with laccases was assessed by two bioassays based on the proliferation index of cells (human mesothelioma cell line MPP89) responsive to EDCs and YES test (Catapane et al. 2013). In this case a common response came out: laccases mediated both chemicals conversion and estrogenic activity lost.

A wide toxicological evaluation would ensure good reliability of water quality. The set-up of a various toxicological toolbox aimed to describe the ecotoxicity and the estrogenic activity of a certain water sample is a recent but attractive vision (Aydin et al. 2015, Leusch et al. 2014, Wildhaber et al. 2015). Enlarging the tested microorganisms and the targeted end-points, it would allow overcoming problems associated to the perturbation activity of some micropollutants on certain model organisms, ultimately making some test not applicable. For example, toxicity of TCS and its products was not possible to be determined by YES assay because of its microbial activity (Cabana et al. 2007b); the toxicity profile before and after the enzymatic treatment was instead elucidated by acute toxicity bioassay based on the crustaceous Daphnia pulex (Arboleda et al. 2013). 
Spina and collaborators (2015) used three ecotoxicological assays (the plant Lepidium sativum, the algae $R$. subcapitata and the luminescent bacteria $V$. fischeri) and two tests for estrogenic activity evaluation (E-screen test and MELN assay) for quality assessment of treated municipal effluents. The out-put data deeply varied: V. fischeri was not sensitive, L. sativum was not disturbed by the wastewater itself but the laccase treatment provoked a significant biostimulation of the plant, $R$. subcapitata pointed out the detoxification of the treated effluent. The two estrogenic activity tests showed a common behavior: the moderate estrogenic activity (EEQ 16-18 ng/l) was completely nullified by laccases.

This multifaceted scenario could require clear guidelines, accepted by the institutions in charge for water control. However, due to the multiple model organisms and endpoints, data obtained from bioassays could be difficult to compare. The interpretation of the results could be improved by the introduction of synthetic indices that summarize data coming from a battery of tests. Some of them have shown their potential to describe wastewaters toxicity (Tigini et al. 2011) but municipal effluents have never taken into consideration.

\section{Conclusion}

In conclusion, fungal biocatalysts (fungal biomass and/or enzymes) demonstrated to be powerful tools for wastewaters treatments. However, the actual goal of researchers, plant engineers, etc. is to evolve bio-based technology from lab scale to industrial level in WTPs, leading to set-up competitive and feasible fungal-based treatments.

Considering the actual state-of-art, the major challenges are: i) use low concentration of micropollutants as closed as possible to environmental relevant problematic; ii) avoid sterility control to assess the fungal capability to compete with autochthonous microflora; iii) verify the strength of biocatalysts in real variable operative conditions i.e municipal wastewaters collected in WTPs; iv) select the most appropriate carriers able to enhance biocatalysts stability and efficiency at industrial scale; v) develop optimal reactor configurations for long operating times; vi) integrate the optimized technology with those already existing and working in WTPs. 


\section{References}

Abejon R, De Cazes M, Belleville MP, Sanchez-Marcano J. Large-scale enzymatic membrane reactors for tetracycline degradation in WWTP effluents. Water Res. 2015;73:118-31.

Amman EM, Gasser CA, Hommes G, Corvini PF-X. Immobilization of defined laccase combinations for enhanced oxidation of phenolic contaminants. Appl Microbiol Biotechnol. 2014;98:1397-1406.

Anastasi A, Spina F, Prigione V, Tigini V, Giansanti P, Varese GC. Scale-up of a bioprocess for textile wastewater treatment using Bjerkandera adusta. Bioresour Technol. 2010;101:3067-75.

Anastasi A, Spina F, Romagnolo A, Tigini V, Prigione V, Varese GC. Integrated fungal biomass and activated sludge treatment for textile wastewaters bioremediation. Bioresour Technol. 2012;123:106-11.

Arboleda C, Cabana H, De Pril E, Peter Jones J, Jiménez GA, Mejía AI, Agathos SN, Penninckx MJ. Elimination of bisphenol A and triclosan using the enzymatic system of autochthonous colombian forest fungi. ISRN biotechnol. 2013;1-12.

Auriol M, Filali-Meknassi Y, Tyagi RD, Adams CD. Laccase-catalyzed conversion of natural and synthetic hormones from a municipal wastewater. Water Res. 2007;41:3281-88.

Auriol M, Filali-Meknassi Y, Adams CD, Tyagi RD, Noguerol T-N, Pina B. Removal of estrogenic activity of natural and synthetic hormones from a municipal wastewater: Efficiency of horseradish peroxidase and laccase from Trametes versicolor. Chemosphere. 2008;70:445-52.

Aydin ME, Aydin S, Tongur S, Kara G, Kolb M, Bahadir M. Application of simple and low-cost toxicity tests for ecotoxicological assessment of industrial wastewaters. Environ Technol. $36 ; 22: 2825-34$.

Baccar R, Blanquez P, Bouzid J, Feki J, Attiya H, Sarra M. Decolourization of a tannery dye: from fungal screening to bioreactor application. Biochem Eng J. 2011;56:184-9.

Baldrian P. Fungal laccases occurrence and properties. FEMS Microbiol Lett. 2006;30:215-42.

Benotti MJ, Trenholm RA, Vanderford BJ, Holaday JC, Standford BD, Snyder SA. Pharmaceuticals and endocrine disrupting compounds in U.S. drinking water. Environ Sci Technol. 2009;43:597-603.

Bicchi C, Schilirò T, Pignata C, Fea E, Cordero C, Canale F, Gilli G. Analysis of environmental endocrine disrupting chemicals using the E-screen method and stir bar sorptive extraction in wastewater treatment plant effluents. Sci Total Environ. 2009;407:1842-51.

Bishop PL, Willett CE. The use and acceptance of other scientifically relevant information (OSRI) in the U.S. Environmental Protection Agency (EPA) Endocrine Disruptor Screening Program. Birth Defects Research (Part B). 2014;101:3-22. 
Blanquez P, Guieysse B. Continuous biodegradation of $17 \beta$-estradiol and $17 \alpha$-ethynylestradiol by Trametes versicolor. J Hazard Mater. 2008;150:459-62.

Bumpus JA, Aust SD. Biodegradation of environmental pollutants by the white rot fungus Phanerochaete chrysosporium: Involvement of the lignin degrading system. Bioassays. 1987;6:166170.

Buchenan ID, Han YS. Assessment of the potential of arthromyces ramosus peroxidase to remove phenol from industrial wastewaters. Environ Technol. 1999;21(5):545-52.

Buchenan ID, Nicell JA. Kinetics of peroxidase interactions in the presence of a protective additive. J Chem Technol Biotechnol. 1998;72: 23-32.

Cabana H, Jones JP, Agathos SN. Elimination of endocrine disrupting chemicals using white rot fungi and their lignin modifying enzymes: a review. Eng Life Sci. 2007a;7:429-56.

Cabana H, Habib Jiwan J, Rozenberg R, Elisashvili V, Penninckx M, Agathos SN, Jones JP. Elimination of endocrine disrupting chemicals nonylphenol and bisphenol A and personal care product ingredient triclosan using enzyme preparation from the white rot fungus Coriolopsis polyzona. Chemosphere 2007b;67:770-78.

Cabana H, Peter Jones J, Agathos SN. Preparation and characterization of cross-linked laccase aggregates and their application to the elimination of endocrine disrupting chemicals. J Biotechnol. 2007c;132:23-31.

Cabana H, Peter Jones J, Agathos SN. Utilization of cross-linked laccase aggregates in a perfusion basket reactor for the continuous elimination of endocrine-disrupting chemicals. Biotechnol Bioeng. 2008:102(6):1582-92.

Cajthaml T, Kresinová Z, Svobodová K, Möder M. Biodegradation of endocrine-disrupting compounds and suppression of estrogenic activity by ligninolytic fungi. Chemosphere. 2009;75:745-50.

Canas AI, Camarero S. Laccases and their natural mediators: biotechnological tools for sustainable eco-friendly processes. Biotechnol Adv. 2010;28:694-705

Castellana G, Loffredo E. Simultaneous removal of endocrine disruptors from a wastewater using white rot fungi and various adsorbents. Water Air Soil Pollut. 2014;225:1872-85.

Catapane M, Nicolucci C, Menale C, Mita L, Rossi S, Mita DG, Diano N. Enzymatic removal of estrogenic activity of nonylphenol and octylphenol aqueous solutions by immobilized laccase from Trametes versicolor. J Hazard Mater. 2013;248-249:337-46.

Cheong S, Yeo S, Song H-G, Choi HT. Determination of laccase gene expression during degradation of 2,4,6-trinitrotoluene and its catabolic intermediates in Trametes versicolor. Microbiol Res. 2006;161:316-20. 
Chou P-H, Lin Y-L, Liu T-C, Chen K-Y. Exploring potential contributors to endocrine disrupting activities in Taiwan's surface waters using yeast assays and chemical analysis. Chemosphere. 2015;138:814-20.

Cruz-Moratò C, Lucas D, Llorca M, Rodriguez-Mozaz S, Gorga M, Petrovic M, Barcelò D, Vicent T, Sarrà M, Marco-Urrea E. Hospital wastewater treatment by fungal bioreactor: Removal efficiency for pharmaceuticals and endocrine disruptor compounds. Sci Total Environ. 2014;493:365-76.

Desai SS, Nityanand C. Microbial laccases and their application: a review. Asian J Biotechnol. 2011;98:98-124.

Diano N, Grano V, Fraconte L, Caputo P, Ricupito A, Attanasio A, Bianco M, Bencivenga U, Rossi S, Manco I, Mita L, Del Pozzo G, Mita DG. Non-isothermal bioreactors in enzymatic remediation of waters polluted by endocrine disruptors: BPA as a model of pollutant. Appl Catal B. 2007;69:252-61.

Domaradzka D, Guzik U, Wojcieszynska D. Biodegradation and biotransformation of polycyclic non-steroidal anti-inflammatory drugs. Rev Environ Sci Biotechnol. 2015;14:229-39.

Faraco V, Piscitelli A, Sannia G, Giardina P. Identification of a new member of the dyedecolorizing peroxidase family from Pleurotus ostreatus. World J Microbiol Biotechnol. 2007;23:889-89.

Fatta-Kassinov D, Vasquez MI, Kümmerer K. Transformation products of pharmaceuticals in surface waters and wastewater formed during photolysis and advanced oxidation processesDegradation, elucidation of byproducts and assessment of their biological potency. Chemosphere. 2011a;85:693-709.

Fatta-Kassinov D, Kalavrouziotis IK, Koukoulakis PH, Vasquez MI. The risks associated with wastewater reuse and xenobiotics in the agroecological environment. Sci Total Environ. 2011b;409:3555-63.

Ferrando-Climent L, Cruz-Morató C, Marco-Urrea E, Vicent T, Sarrà M, Rodriguez-Mozaz S, Barceló D. Non conventional biological treatment based on Trametes versicolor for the elimination of recalcitrant anticancer drugs in hospital wastewater. Chemosphere 2015;136:9-19.

Flint S, Markle T, Thompson S, Wallace E. Bisphenol A exposure, effects, and policy: A wildlife perspective. J Environ Manage. 2012;104:19-34.

Frye CA, Bo E, Calamandrei G, Calza L, Dessı'-Fulgheri F, Fernandez M, Fusani L, Kah O, Kajta M, Le Page Y, Patisaul HB, Venerosi A, Wojtowicz AK, Panzica GC. Endocrine disrupters: a review of some sources, effects, and mechanisms of actions on behaviour and neuroendocrine systems. J Neuroendocrinol. 2011;24: 144-59. 
Fuhrman VF, Tal A, Arnon S. Why endocrine disrupting chemicals (EDCs) challenge traditional risk assessment and how to respond . J Hazard Mater. 2015;286:589-611.

Gao D, Du L, Yang J, Wu W, Liang H. A critical review of the application of white rot fungus to environmental pollution control. Crit Rev Biotechnol. 2010;30:70-7.

Garcia HA, Hoffman CM, Kinney KA, Lawler DF. Laccase-catalyzed oxidation of oxybenzone in municipal wastewater primary effluent. Water res. 2011;45:1921-32.

Garcia-Morales R, Rodríguez-Delgado M, Gomez-Mariscal K, Orona-Navar C, Hernandez-Luna C, Torres E, Parra R, Cárdenas-Chávez D, Mahlknecht J, Ornelas-Soto N. Biotransformation of endocrine-disrupting compounds in groundwater: bisphenol A, nonylphenol, ethynylestradiol and triclosan by a laccase cocktail from Pycnoporus sanguineus CS43. Water Air Soil Pollut. 2015;226:251-265.

Gasser CA, Hommes G, Schaffer A, Corvini PF-X. Multi-catalysis reactions: new prospects and challenges of biotechnology to valorize lignin. Appl Microbiol Biotechnol. 2012;95:1115-34.

Gasser CA, Amman EM, Shahgaldian P, Corvini PF-X. Laccases to take on the challenge of emerging organic contaminants in wastewater. Appl Microbiol Biotechnol. 2014a;98:9931-52.

Gasser CA, Yu L, Svojitka J, Wintgens T, Amman EM, Shahgaldian P, Corvini FP-X, Hommes G. Advanced enzymatic elimination of phenolic contaminants in wastewater: a nano approach at field scale. Appl Microbiol Biotechnol. 2014b:98:3305-16.

Glenn JK, Gold MH. Decolorization of several polymeric dyes by the lignin-degrading basidiomycete Phanerochaete chrysosporium. Appl Environ Microbiol. 1983;45:1741-47.

Haroune L, Saibi S, Bellenger J-P, Cabana H. Evaluation of the efficiency of Trametes hirsuta for the removal of multiple pharmaceutical compounds under low concentrations relevant to the environment. Bioresour Technol. 2014:171:199-202.

Hata T, Shintate H, Kawai S, Okamura H, Nishida T. Elimination of carbamazepine by repeated treatment with laccase in the presence of 1-hydroxybenzotriazole. J Hazard Mater. 2010;181:117578.

Heinfling A, Martınez MJ, Martınez AT, Bergbauer M, Szewzyk U. Purification and characterization of peroxidases from the dye-decolorizing fungus Bjerkandera adusta. FEMS Microbiol Lett. 1998;165:43-50.

Hommes G, Gasser CA, Amman EM, Corvini PF-X. Determination of oxidoreductase activity using a high-throughput microplate respiratory measurement. Anal Chem. 2013;85:283-91.

Hou J, Dong G, Luu B, Sengpiel RG, Ye Y, Wessling M, Chen V. Hybrid membrane with $\mathrm{TiO}_{2}$ based bio-catalytic nanoparticle suspension system for the degradation of bisphenol-A. Bioresour Technol. 2014;169:475-83. 
Illés E, Szabò E, Takàcs E, Wojnárovits L, Dombi A, Gajda-Schrantz K. Ketoprofen removal by $\mathrm{O}_{3}$ and $\mathrm{O}_{3} / \mathrm{UV}$ processes: Kinetics, transformation products and ecotoxicity. Sci Total Environ. 2014;472:178-84.

Inoue Y, Hata T, Kawai S, Okamura H, Nishida T. Elimination and detoxification of triclosan by manganese peroxidase from white rot fungus. J Hazard Mater. 2010;180:764-67.

Jarošová B, Erseková A, Hilscherová K, Loos R, Gawlik BM, Giesy JP, Bláha L. Europe-wide survey of estrogenicity in wastewater treatment plant effluents: the need for the effect-based monitoring. Environ Sci Pollut Res. 2014a;21:10970-82.

Jarošová B, Bláha L, Giesy JP, Hilscherová K. What level of estrogenic activity determined by in vitro assays in municipal waste waters can be considered as safe? Environ Int. 2014;64:98-109.

Jelic A, Cruz-Moratò C, Marco-Urrea E, Sarrà M, Perez A, Vicent T, Petrovic M, Barcelo D. Degradation of carbamazepine by Trametes versicolor in an air pulsed fluidized bed bioreactor and identification of intermediates. Water res. 2012;46:955-64.

Kallqvist T, Milacic R, Smital T, Thomas KV, Vranes S, Tollefsen K-E. Chronic toxicity of the Sava River (SE Europe) sediments and river water to the algae Pseudokirchneriella subcapitata. Water res. 2008;42:2146-56.

Kaushik P, Malik A. Fungal dye decolourisation: recent advances and future potential. Environ Int. 2009;35:127-41.

Katsigiannis A, Noutsopoulos C, Mantziaras J, Gioldasi M. Removal of emerging pollutants through Granular Activated Carbon. Chem Eng J. 2015;280:49-57.

Khlifi-Slama R, Mechichi T, Sayadi S, Dhouib A. Effect of natural mediators on the stability of Trametes trogii laccase during the decolourization of textile wastewaters. J Microbiol. 2012;50:22634.

Kim Y, Yeo S, Song H, Choi HT. Enhanced expression of laccase during the degradation of endocrine disrupting chemicals in Trametes versicolor. J Microbiol. 2008;46:402-7.

Kim Y-J, Nicell JA. Laccase-catalysed oxidation of aqueous triclosan. J Chem Technol Biotechnol. 2006a;81:1344-52.

Kim Y-J, Nicell JA. Impact of reaction conditions on the laccase-catalyzed conversion of bisphenol A. Bioresour Technol. 2006b;97:1431-42.

Kim YJ, Nicell JA. Laccase-catalyzed oxidation of bisphenol A with the aid of additives. Process Biochem. 2006c;41:1029-37.

Kum H, Kim MK, Choi HT. Degradation of endocrine disrupting chemicals by genetic transformants in Irpex lacteus with an inducible laccase gene of Phlebia tremellosa. Biodegradation 2009;20:673-8. 
Kunamneni A, Camarero S, Garcia-Burgos C, Plou FJ, Ballesteros A, Alcalde M. Engineering and applications of fungal laccases for organic synthesis. Microb Cell Fact. 2008;7:1-17.

Lee S, Koo B, Choi J, An B, Jeung E, Choi I. Degradation of bisphenol A by white rot fungi, Stereum hirsutum and Heterobasidium insulare, and reduction of its estrogenic activity. Biol Pharm Bull. 2005;28:201-7.

Lee Y, Escher BI, Von Gunten U. Efficient removal of estrogenic activity during oxidative treatment of waters containing steroid estrogens. Environ Sci Technol. 2008;42(17):6333-9.

Leusch FDL, Khan SJ, Laingam S, Prochazka E, Froscio S, Trinh T, Chapman HF, Humpage A. Assessment of the application of bioanalytical tools as surrogate measure of chemical contaminants in recycled water. Water Res. 2014;49:300-15.

Levin L, Meligrani E, Ramos AM. Effect of nitrogen sources and vitamins on ligninolytic enzyme production by some white-rot fungi. Dye decolorization by selected culture filtrates. Bioresour Technol. 2010;101:4554-63.

Li Z, Xiang X, Li M, Ma Y, Wang J, Liu X. Occurrence and risk assessment of pharmaceuticals and personal care products and endocrine disrupting chemicals in reclaimed water and receiving groundwater in China. Ecotoxicol Environ Saf. 2015;119:74-80.

Libardi Junior N, Gern RMM, Furlan SA, Schlosser D. Laccase production by the aquatic ascomycete Phoma sp. UHH 5-1-03 and the white rot basidiomycete Pleurotus ostreatus DSM 1833 during submerged cultivation on banana peels and enzyme applicability for the removal of endocrine-disrupting chemicals. Appl Biochem Biotechnol. 2012;167:1144-56.

Liers C, Bobeth C, Pecyna M, Ullrich R, Hofrichter M. DyP-like peroxidases of the jelly fungus Auricularia auricula-judae oxidize nonphenolic lignin model compounds and high-redox potential dyes. App Microbiol Biotechnol. 2010;85:1869-79.

Liu Z, Lu G, Yin H, Dang Z. Estimated human excretion rates of natural estrogens calculated from their concentrations in raw municipal wastewater and its application. Environ Sci Pollut Res, 2015;22:9554-62.

Lloret L, Eibes G, Lú-Chau TA, Moreira MT, Feijoo G, Lema JM. Laccase-catalyzed degradation of anti-inflammatories and estrogens. Biochem Eng J. 2010;51:124-31.

Lloret L, Hollmann F, Eibes G, Feijoo G, Moreira MT, Lema JM. Immobilisation of laccase on Eupergit supports and its application for the removal of endocrine disrupting chemicals in a packedbed reactor. Biodegradation. 2012a;23:373-86.

Lloret L, Eibes G, Feijoo G, Moreira MT, Lema JM. Degradation of estrogens by laccase from Myceliophthora thermophila in fed-batch and enzymatic membrane reactors. J Hazard Mater. 2012b; 213-214:175-83. 
Lloret L, Eibes G, Feijoo G, Moreira MT, Lema JM. Application of response surface methodology to study the removal of estrogens in a laccase-mediated continuous membrane reactor. Biocatal Biotransformation. 2013;31(4):197-207.

Lundstrom E, Adolfsson-Erici M, Alsberg T, Bjorlenius B, Eklund B, Laven M, Breitholtz M. Characterization of additional sewage treatment technologies: Ecotoxicological effects and levels of selected pharmaceuticals, hormones and endocrine disruptors. Ecotox Environ Safe. 2010;73:161219.

Luo Y, Guo W, Ngo HH, Nghiem LD, Hai FI, Zahng J, Liang S, Wanj XC. A review on the occurrence of micropollutants in the aquatic environment and their fate and removal during wastewater treatment. Sci Total Environ. 2014;473-474:619-41.

Macellaro G, Pezzella C, Cicatiello P, Sannia G, Piscitelli A. Fungal laccases degradation of endocrine disrupting compounds. Biomed Res Int. 2014:1-8.

Majeau J, Brar SK, Tyagi RD. Laccases for removal of recalcitrant and emerging pollutants. . Bioresour Technol. 2010;101:2331-50.

Marco-Urrea E, Perez-Trujillo M, Vicent T, Caminal G. Ability of white-rot fungi to remove selected pharmaceuticals and identification of degradation products of ibuprofen by Trametes versicolor. Chemosphere. 2009;74:765-72.

Marco-Urrea E, Perez-Trujillo, Cruz-Morato C, Caminal G, Vicent T. Degradation of the drug sodium diclofenac by Trametes versicolor pellets an identification of some intermediates by NMR. J Hazard Mater. 2010a;176:836-42.

Marco-Urrea E, Perez-Trujillo M, Blanquez P, Vicent T, Caminal G. Biodegradation of the analgesic naproxen by Trametes versicolor and identification of the intermediates using HPLCDAD-MS and NMR. Bioresour Technol. 2010b;101:2159-66.

Margot J, Maillard J, Rossi L, Barry DA, Holliger C. Influence of treatment conditions on the oxidation of micropollutants by Trametes versicolor laccase. New Biotechnol. 2013;30(6):803-13.

Martınez MJ, Martınez AT. Characterization of MnP isoenzymes of Pleurotus eryngii exhibiting Mn-independent activities on 2,6-dimethoxyphenol and veratryl alcohol. In: Messner K, Srebotnik E, editors. Biotechnology in the pulp and paper industry: recent advances in applied and fundamental research. Vienna: Facultas-Universitatsverlag, 1996;417-20.

Maruyama T, Komatsu C, Michizoe J, Ichinose H, Goto M. Laccase-mediated oxidative degradation of the herbicide dymron. Biotechnol Prog. 2006;22:426-30.

Melcer H, Klecka G. Treatment of wastewaters containing bisphenol A: state of science review. Water Environ Res. 2011;83(7):650-66. 
Mendonca E, Picado A, Paixao SM, Silva L, Cunha MA, Leitao S, Moura I, Cortez C, Brito F. Ecotoxicity tests in the environmental analysis of wastewater treatment plants: Case study in Portugal. J Hazard Mater. 2009;163:665-70.

Mersha MD, Patel BM, Patel D, Richardson BN, Dhillon HS. Effects of BPA and BPS exposure limited to early embryogenesis persist to impair non-associative learning in adults. Behav Brain Funct. 2015;11:27.

Meyer H, Munch T. Swiss Industrial Biocatalysis Consortium. BioWorld Europe 2005;1:14-16.

Mizuno H, Hirai H, Kawai S, Nishida T. Removal of estrogenic activity of iso-butylparaben and nbutylparaben by laccase in the presence of 1-hydroxybenzotriazole. Biodegradation. 2009;20:533-9. Mompelat S, Le Bot B, Thomas O. Occurrence and fate of pharmaceutical products and byproducts, from resource to drinking water. Environ Int. 2009;35:803-14.

Morozova OV, Shumakovich GP, Shleev SV, Yaropolov YI. Laccase-mediator systems and their applications: a review. Appl Biochem Microbiol. 2007;43:523-35.

Mougin C, Kollmann A, Jolivalt C. Enhanced production of laccase in the fungus Trametes versicolor by the addition of xenobiotics. Biotechnol Lett. 2002;24:139-42.

Murugesan K, Chang Y, Kim Y, Jeon J, Kim E, Chang Y. Enhanced transformation of triclosan by laccase in the presence of redox mediators. Water res. 2010;44:298-308.

Nicolucci C, Rossi S, Menale C, Godjevargova T, Ivanov Y, Bianco M, Mita L, Bencivenga U, Mita DG, Diano N. Biodegradation of bisphenols with immobilized laccase or tyrosinase on polyacrylonitrile beads. Biodegradation. 2011;22:673-83.

Novotny C, Svobodová K, Benada O, Kofronová O, Heissenberger A, Fuchs W. Potential of combined fungal and bacterial treatment for color removal in textile wastewater. Bioresour Technol. 2011;102:879-88.

Nguyen LN, Hai FI, Price WE, Leusch FDL, Roddick F, McAdam EJ, Magram SF, Nghiem LD. Continuous biotransformation of bisphenol A and diclofenac by laccase in an enzymatic membrane reactor. Int Biodeterior Biodegradation. 2014;95:25-32.

Oulton RL, Kohn T, Cwiertny DM. Pharmaceuticals and personal care products in effluent matrices: A survey of transformation and removal during wastewater treatment and implications for wastewater management. J Environ Monit. 2010;12:1956-78.

Piscitelli A, Giardina P, Lettera V, Pezzella C, Sannia G, Farmaco V. Induction and transcriptional regulation of laccases in fungi. Curr Genomics. 2011;12:104-12.

Prieto A, Vallejo A, Zuloaga O, Paschke A, Sellergen B, Schillinger E, Schrader S, Moder M. Selective determination of estrogenic compounds in water by microextraction by packed sorbents 
and a molecularly imprinted polymer coupled with large volume injection-in-port-derivatization gas chromatography-mass spectrometry. Anal Chim Acta. 2011;703:41-51.

Purchase IFH. Ethical review of regulatory toxicology guidelines involving experiments of animals: the example of endocrine disrupters. Toxicol Sci. 1999;52:141-7.

Ra J-S, Lee S-H, Lee J, Kim HY, Lim BJ, Kim SH, Kim SD. Occurrence of estrogenic chemicals in South Korean surface waters and municipal wastewaters. J Environ Monit. 2011;13:101-9.

Reungoat J, Macova M, Escher BI, Carswell S, Mueller JF, Keller J. Removal of micropollutants and reduction of biological activity in a full scale reclamation plant using ozonation and activated carbon filtration. Water res. 2010;44:625-37.

Riva S. Laccases: blue enzymes for green chemistry. Trends microbiol. 2006;24:219-26.

Rodriguez-Rodriguez CE, Jelic A, Pereira MA, Sousa DZ, Petrovic M, Alves MM, Barcelò D, Caminal G, Vicent T. Bioaugmentation of sewage sludge with Trametes versicolor in solid-phase biopiles produces degradation of pharmaceuticals and affects microbial communities. Environ Sci Technol. 2012;46:12012-20.

Schilirò T, Pignata C, Rovere R, Fea E, Gilli G. The endocrine disrupting activity of surface waters and of wastewater treatment plant effluents in relation to chlorination. Chemosphere. 2009;75:33540.

Sei K, Takeda T, Soda SO, Fujita M, Ike M. Removal characteristicsn of endocrine-disrupting chemicals by laccase from white-rot fungi. J Environ Sci Health A. 2008;43:53-60.

Snyder SA, Westerhoff P, Yoon Y, Sedlak DL. Pharmaceuticals, personal care products, and endocrine disruptors in water: implications for the water industry. Environ Eng Sci. 2003;20:44969.

Soares A, Jonasson K, Terrazas E, Guieysse B, Mattiasson B. The ability of white-rot fungi to degrade the endocrine-disrupting compound nonylphenol. Appl Microbiol Biotechnol. 2006;66:719-25.

Songulashvili G, Jimenez-Tobon GA, Jaspers C, Penninckx MJ. Immobilized laccase of Cerrena unicolor for elimination of endocrine disruptor micropollutants. Fungal Biol. 2012;116:883-9.

Soupilas A, Papadimitriou CA, Samaras P, Gudulas K, Petridis D. Monitoring of industrial effluent ecotoxicity in the greater Thessaloniki area. Desalination. 2008;224:261-70.

Spina F, Cordero C, Schilirò T, Sgorbini B, Pignata C, Gilli G, Bicchi C, Varese GC. Removal of micropollutants by fungal laccases in model solution and municipal wastewater: evaluation of estrogenic activity and ecotoxicity. J Clean Prod. 2015:100:185-94.

Strong PJ, Claus H. Laccase: A Review of its past and its future in bioremediation. Crit Rev Env Sci Technol. 2010;41:373-434. 
Suda T, Hata T, Kaway S, Okamura H, Nishida T. Treatment of tetracycline antibiotics by laccase in the presence of 1-hydroxybenzotriazole. Bioresour Technol. 2012;103:498-501.

Sung E, Turan N, Ho PWL, Ho SL, Jarratt PDB, Waring RH, Ramsden DB. Detection of endocrine disruptors - from simple assays to whole genome scanning. Int J Androl. 2012;35:407-14.

Sun Y, Huang H, Sun Y, Wang C, Shi X-L, Hu H-Y, Kameya T, Fujie K. Ecological risk of estrogenic endocrine disrupting chemicals in sewage plant effluent and reclaimed water. Environ Pollut. 2013;180:339-44.

Taboada-Puig R, Lu-Chau TA, Eibes G, Feijoo G, Moreira MT, Lema JM. Continuous removal of endocrine disruptors by versatile peroxidase using a two-stage system. Biotechnol Prog. 2015;31(4):908-16.

Tien M, Kirk TK. Lignin-degrading enzyme from the Hymenomycete Phanerochaete chrysosporium Burds. Science. 1983;221:661-3.

Tigini V, Giansanti P, Mangiavillano A, Pannocchia A, Varese GC. Evaluation of toxicity, genotoxicity and environmental risk of simulated textile and tannery wastewaters with a battery of biotests. Ecotoxicol Environ Saf. 2011;74:866-73.

Torres E, Bustos-Jaimes I, Le Borgne S. Potential use of oxidative enzymes for the detoxification of organic pollutant. Appl Catal B. 2003;46:1-15.

Torres-Duarte C, Roman R, Tinoco R, Vazquez-Duhalt R. Halogenated pesticide transformation by a laccase-mediator system. Chemosphere. 2009;77:687-92.

Torres-Duarte C, Viana MT, Vazquez-Duhalt R. Laccase-mediated transformations of endocrine disrupting chemicals abolish binding affinities to estrogen receptors and their estrogenic activity in zebrafish. Appl Biochem Biotechnol. 2012;168(4):864-76.

Touraud E, Roig B, Sumpter JB, Coetsier C. Drug residues and endocrine disruptors in drinking water: risk for humans? Int J Hyg Environ Health. 2011;214:437-41.

Tran NH, Hu J, Urase T. Removal of the insect repellent N,N-diethyl-m-toluamide (DEET) by laccase-mediated systems. Bioresour Technol. 2013;147:667-71.

Vulliet E, Cren-Olive C, Grenier-Loustalot M. Occurrence of pharmaceuticals and hormones in drinking water treated from surface waters. Environ Chem Lett. 2011;9:103-14.

Wang J, Majima N, Hirai H, Kawagishi H. Effective Removal of endocrine-disrupting compounds by lignin peroxidase from the white-rot fungus Phanerochaete sordida YK-624. Curr Microbiol. 2012;64:300-3.

Weng S-S, Liu S-M, Lai H-T. Application parameters of laccase-mediator systems for treatment of sulfonamide antibiotics. Bioresour Technol. 2013;141:152-9. 
Wildhaber YS, Mestankova H, Scharer M, Schirmer K, Salhi E, von Gunten U. Novel test procedure to evaluate the treatability of wastewater with ozone.Water res. 2015;75:324-35.

Wuttke W, Jarry H, Seidlov $\alpha$-Wuttke D. Definition, classification and mechanism of action of endocrine disrupting chemicals. Hormones. 2010;9:9-15.

Yang M, Wang K, Shen Y, Wu M. Evaluation of estrogenic activity in surface waters and municipal wastewaters in Shanghai, China. Bull Environ Contam Toxicol. 2011;87:215-9.

Yu C-P, Roh H, Chu K-H. 17ß-estradiol-degrading bacteria isolated from activated sludge. Environ Sci Technol. 2007;41:486-92.

Zhang Y, Geißen S-U. Elimination of carbamazepine in a non-sterile fungal bioreactor. Bioresour Technol. 2012;112:221-7. 


\section{Abbreviations}

EPA: environmental protection agency

EC: European Commission

EDCs: endocrine disrupting chemicals

BPA: bisphenol A

PCPs: personal care products

WTP: wastewater treatment plant

EEQ: $17 \beta$-estradiol equivalent concentration

NP: nonylphenol

TCS: triclosan

HBT: hydroxybenzotriazole

ABTS: 2,2'-azino-bis(3-etilbenzotiazolin-6-sulfonico)

PEG: polyethylene glycol

YES: yeast estrogen screen assay

E-screen test: human breast cancer cell line (MCF-7 BUS) proliferation test

MELN assay: luciferase-transfected human breast cancer cell line gene reporter assay 